\title{
IMPLIKASI PENETAPAN STATUS TERSANGKA BAGI BUPATI TERPILIH TERHADAP PEMILIHAN UMUM KEPALA DAERAH DALAM SISTEM KETATANEGARAAN REPUBLIK INDONESIA
}

\author{
Dyah Kemala Sintha \\ Sekretaris Daerah Kota Tegal, Jawa Tengah \\ E-mail: shintha.dyahkemala@gmail.com
}

\begin{abstract}
Under the provisions of Article 31 paragraph (1) of Law Number 32 Year 2004 on Regional Government states that, in the head region and/or deputy regional head suspended by the President without going through Parliament because the proposal was convicted of corruption, terrorism, treason, and/or a crime against state security. The article 31 paragraph (2) of Law Number 32 Year 2004 on Regional Head if found guilty by the court decision, the Regents may be dismissed. However, the anticorruption gives another reason that, Regent who has been declared a suspect is not good to hold office, so it is polemical. This study aimed to analyze the determination of the status of the suspect for the Regent elected as a condition. In addition it also aimed to analyze the implications of determining the status of a suspect for the Regent elected in the general election of regional heads in the constitutional system of the Republic of Indonesia, with reaserch method of yuridis normatif.

Determination of the status of the suspect for the regents elected is not a limiting factor for someone to be sworn in as regent. There are two factors that hinder a person inducted into the Regional Head, which is being accused of corruption, terrorism, treason, and/or a crime against state security or convicted of treason and/or other actions that may divide the Republic of Indonesia declared by a court decision that has obtained permanent legal force. Implications for the determination of the status of a suspect in the Elected Regent regional head elections in the constitutional system of the Republic of Indonesia is divided into three implications are the implications of Ethics and Social namely the determination of the status of suspects for Elected Regent cause public distrust of the government. Political implications that gave birth to the other party the opportunity to become head of the region, as well as the legal implications of determining the status of a suspect for Regent ie not inhibit a person to induct regent elected as regent, since the Local Government Act only regulates the dismissal of the Regent, Regent's selected instead.
\end{abstract}

Key Word: regent, implementation, and prinsons status

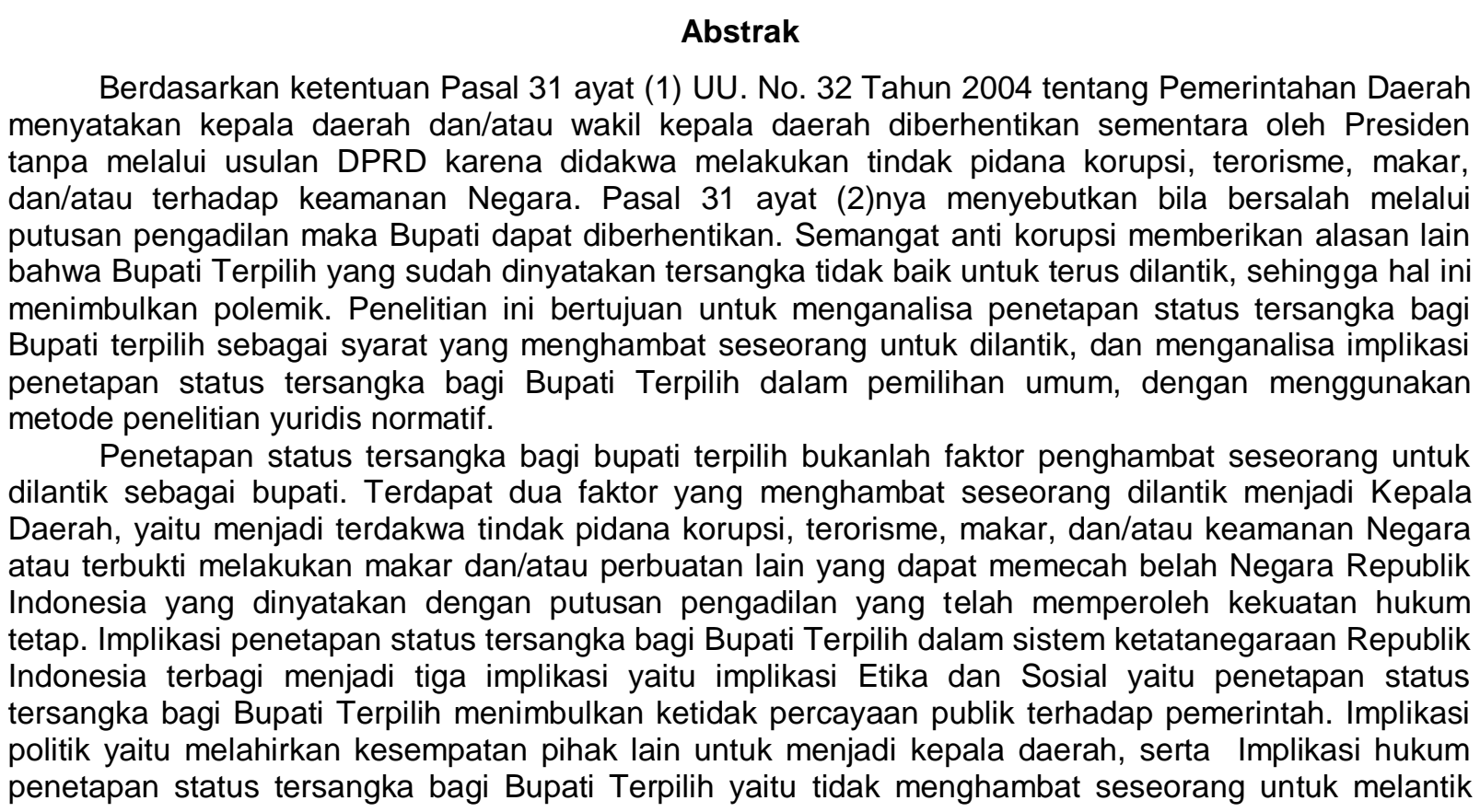


bupati terpilih, karena dalam undang-undang hanya mengatur pemberhentian Bupati, bukan Bupati Terpilih.

Kata Kunci: Bupati, Implikasi, dan Status Tersangka

\section{PENDAHULUAN}

Secara normatif Pasal 97 ayat (1) PP 49 Tahun 2008 Tentang Perubahan Ketiga Atas Peraturan Pemerintah Nomor 6 Tahun 2005 Tentang Pemilihan, Pengesahan Pengangkatan, Dan Pemberhentian Kepala Daerah Dan Wakil Kepala Daerah, menyatakan bahwa, yang membuat kepala daerah terpilih tidak dilantik adalah jika ia berhalangan tetap. Jika calon kepala daerah terpilih berhalangan tetap, calon wakil kepala daerah terpilih dilantik menjadi kepala daerah, namun demikian tidak disebutkan apa yang dimaksud dengan "berhalangan tetap". Pasal 124 Peraturan Pemerintah Nomor 6 Tahun 2005 Tentang Pemilihan, Pengesahan Pengangkatan, Dan Pemberhentian Kepala Daerah Dan Wakil Kepala Daerah juga menyatakan, kalaupun dilakukan pelantikan karena status sebagai tersangka dianggap bukan "halangan tetap", Bupati/walikota/gubernur dapat diberhentikan sementara jika dinyatakan melakukan tindak pidana kejahatan yang diancam dengan pidana penjara paling singkat 5 (lima) tahun atau lebih berdasarkan putusan pengadilan.

Pasal 125 Peraturan Pemerintah Nomor 6 Tahun 2005 Tentang Pemilihan, Pengesahan Pengangkatan, Dan Pemberhentian Kepala Daerah Dan Wakil Kepala Daerah kemudian mengatur bahwa, apabila terbukti melakukan tindak pidana kejahatan yang diancam dengan hukuman penjara paling singkat 5 (lima) tahun atau lebih berdasarkan putusan pengadilan yang telah mempunyai kekuatan hukum tetap, dapat diberhentikan (pemberhentian tetap) oleh pihak yang berwenang melakukan pemberhentian.

Pada ranah kenegaraan tentunya aturan protokoler tersebut sudah jelas, bahwa Bupati terpilih harus dilantik terlebih dahulu, baru ketika Bupati terpilih dikenakan status terdakwa berdasarkan ketentuan Pasal 31 ayat (1) Undang-Undang Nomor 32 Tahun 2004 tentang Pemerintahan Daerah menyatakan bahwa, kepala daerah dan/atau wakil kepala daerah diberhentikan sementara oleh Presiden tanpa melalui usulan DPRD karena didakwa melakukan tindak pidana korupsi, tindak pidana terorisme, makar, dan/atau tindak pidana terhadap keamanan Negara. Selain itu menurut Pasal 31 ayat (2) UU No 32 Tahun 2004 tentang Pemerintahan Daerah apabila Kepala Daerah dinyatakan bersalah melalui putusan pengadilan maka, Bupati tersebut dapat diberhentikan. Namun semangat anti korupsi yang meggelora memberikan alasan lain bahwa, Bupati Terpilih yang sudah dinyatakan tersangka tidak baik untuk terus dilantik. Sehingga hal ini menimbulkan polemik, dimana KPK menolak pelantikan tersebut pada kasus Hambit Bintih.

Pada ranah kenegaraan Bupati terpilih yang belum dilantik sebagai Bupati, tentunya belum memiliki status, namun demikian bagaimanakah pemberhentiannya dalam koridor ketatanegaraan. Hal ini tentunya sulit, karena minimnya penjelasan undang-undang. Untuk itu perlu kajian normative terhadap implikasi penetapan status tersangka bagi Bupati Terpilih dalam pemilihan umum kepala 
daerah dalam sistem ketatanegaraan Republik Indonesia. Dikarenakan kasus yang terjadi berada dalam yurisdiksi UU Nomor 32 Tahun 2004 tentang Pemerintahan Daerah, maka sebagai suatu kajian akademis UU No 32 Tahun 2004 tetap dipergunakan, namun dilakukan komparasi pula terhadap Undang Undang 23 Tahun 2014 tentang Pemerintahan Daerah, untuk menghasilkan kajian yang lengkap.

\section{METODE PENELITIAN}

Metode penulisan dengan menggunakan teks naratif, dan pendekatan Yuridis Normatif. Metode pengambilan data dilakukan secara studi kepustakaan atau studi dokumen, dengan analisis secara kualitatif.

\section{PERUMUSAN MASALAH}

Berdasarkan latar belakang masalah diatas, dirumuskan masalah sebagai berikut: Pertama, Implikasi penetapan status tersangka bagi Bupati Terpilih dalam pemilihan umum kepala daerah dalam sistem ketatanegaraan Republik Indonesia; Kedua, Penetapan Status Tersangka Bagi Bupati Terpilih dan Faktor Penghambat Seseorang Untuk Dilantik Sebagai Bupati

\section{PEMBAHASAN}

Implikasi penetapan status tersangka bagi Bupati Terpilih dalam pemilihan umum kepala daerah dalam sistem ketatanegaraan

\section{Republik Indonesia}

Penetapan status tersangka bagi bupati terpilih bukanlah faktor penghambat seseorang untuk dilantik sebagai bupati. Terdapat dua faktor yang menghambat seseorang dilantik menjadi Kepala Daerah, yaitu menjadi ter- dakwa sesuai dengan Pasal 31 dan Pasal 83 UU No 23 tahun 2014. Selain itu faktor yang menghambat seseorang dilantik menjadi Kepala Daerah, yaitu berhalangan tetap, sesuai Pasal 29 Ayat (2) Huruf b dan Pasal 139 Ayat (2) Huruf b UU No 23 tahun 2014. Mengapa Hambit Bintih tidak dapat dilantik menjadi Bupati, padahal saat itu ia hanya sebagai tersangka, dan tersangka dilindungi oleh undang-undang karena belum tentu bersalah.

Hal inilah yang menjadi banyak fenomena di Indonesia, bukan hanya terhadap fenomena kepala daerah, tetapi juga jabatan public lainnya yang tidak mengatur bahwa seorang tersangka tidak bias di lantik, misalnya pada kasus pengangkatan Budi Gunawan sebagai Kapolri. Fenomena tersebut memiliki cirri yang sama menurut penulis yaitu: (a) Sama sama ditetapkan menjadi tersangka; (b) Sama sama terdapat penolakan oleh masyarakat; (c) Sama-sama menghadapi KPK Fenomena ini sebetulnya dapat dianalisis, bahwa saat ini masyarakat merasa marah dengan adanya korupsi, oleh karena itu setiap pemberantasan korupsi adalah poin utama untuk menegakan hukum. Hanya KPKlah yang mampu menegakan hukum, oleh karena itu setiap tindakan yang diatasnamakan pemberantasan korupsi pastilah popular dimata masyarakat. Anis Matta mengungkapkan bahwa mengevaluasi atau mengkritisi kinerja KPK, tidak sama dengan sikap mendukung para koruptor. ${ }^{1}$

\footnotetext{
Aries Setiawan dan Mohammad Adam, Anis: Kritik KPK Bukan Berarti Pro Koruptor "Kalau sekarangan orang takut mengkritik KPK, karena takut dituduh pro koruptor."http://nasional.news.viva.co.id/news/read/25 3267-kritik-kpk-bukan-berarti-pro-koruptor, diakses pada tanggal 18 Februari 2015.
} 
Hal ini mengakibatkan banyak masyarakat takut mengkritik KPK, selain itu penetapa seorang tersangka oleh KPK selalu menjadi vonis kematian, artinya seseorang sudah diadili pada saat KPK menetapkan seseorang menjadi tersangka, karena KPK tidak memiliki kewenangan SP3. Namun demikian penegakan hukum yang dapat dilihat adalah, menurunnya kehati-hatian KPK dalam menetapkan tersangka, hal ini banyak terjadi seperti pada kasus Surya Darma Ali dan penetapan tersangka lainnya.

Apabila dikaji dari segi pemerintahan, sangat terlihat bahwa isu pelemahan KPK ternyata juga dapat membawa akibat penghentian kasus, hal ini terjadi pada kasus Chandra M. Hamzah dan Bibit Samad Rianto yang di deponeringkan. Isu pelemahan KPK justru membuat masyarakat semakin mendesak dan ikut mendukung KPK, walaupun hingga sekarang tidak dapat diketahui mana yang benar dan mana yang salah.

Penetapan status tersangka bagi bupati terpilih saat ini ternyata menjadi faktor penghambat, disesabkan oleh pergeseran kepastian hukum yaitu karena: (1) Tuntutan/ desakan masyarakat luas; (2) Etika politik; (3) Efisiensi Pemerintahan.

Dalam konteks tersebut, penulis melihat adanya pergeseran kepastian hukum Rechtmatig kearah Doelmatig atau kemanfaatan diluar faktor hukum. Dalam konteks bernegara sebagaimana dikatakan Gustav Radbruch bahwa hukum sering sekali terjadi tarikmenarik unsur hokum yang menghasilkan ketegangan (Spannungsverhaltnis). Hal ini terjadi karena ketiganya berisi tuntutan yang berlainan dan mengandung potensi untuk saling bertentangan. ${ }^{2}$

Dikaji dari segi kepastian hukum, maka jelas bahwa penetapan status tersangka bagi bupati terpilih bukanlah faktor penghambat seseorang untuk dilantik sebagai bupati. Terdapat dua faktor yang menghambat seseorang dilantik menjadi Kepala Daerah yaitu menjadi terdakwa dan berhalangan tetap. Oleh karea itu pelantikan harus tetap dilaksanakan untuk menetapkan status seseorang, atau melakukan penundaan hingga bupati terpilih menjadi terdakwa, namun disi lain pelaksanaan pelantikan bupati yang telah ditetapkan sebagai tersangka akan mencederai gerakan anti korupsi yang dijunjung tinggi masyarakat, tidak patut bahkan tidak bermoral.

Kepastian hukum mengharuskan diciptakannya peraturan-peraturan umum atau kaedah-kaedah yang berlaku umum yang pelaksanaannya harus diabdikan untuk kepentingan masyarakat, serta kepastian hukum harus diwujudkan dalam tertib hukum. ${ }^{3}$ Oleh karena itu secara administrative sudah sepantasnya pelantikan dilaksanakan sebagaimana pelantikan bupati terdahulu yang juga ditetapkan sebagai tersangka.

Sebagaimana pendapat Gustav Radbruch, sisi kemanfaatan juga menjadi pertentangan terhadap kepastian hukum. Teori utilitas lebih menekankan bahwa pengambilan keputusan etika dengan pertimbangan manfaat terbesar bagi banyak pihak sebagai hasil akhirnya (the greatest good for the greatest number). Artinya, bahwa hal yang benar

\footnotetext{
2 Satjipto Rahardjo, 2006, IImu Hukum, Citra Aditya Bakti, Bandung, hal. 19.

3 Soerjono Soekanto, 1984, Beberapa Permasalahan Hukum Dalam Kerangka Pembangunan di Indonesia, Penerbit Universitas Indonesia, Yogyakarta, hal. 55
} 
didefinisikan sebagai hal yang memaksimalisasi apa yang baik atau meminimalisir apa yang berbahaya bagi kebanyakan orang. Semakin bermanfaat pada semakin banyak orang, perbuatan itu semakin etis. Dasar moral dari perbuatan hukum ini bertahan paling lama dan relative paling banyak digunakan. Aliran atau paham Utilitarium sering disebut pula dengan aliran konsekuensialisme karena sangat berorientasi pada hasil perbuatan. ${ }^{4}$

Prinsip utilitarisme menyatakan bahwa, "Suatu tindakan dianggap benar dari sudut pandang etis jika dan hanya jika jumlah total utilitas yang dihasilkan dari tindakan tersebut lebih besar dari jumlah utilitas total yang dihasilkan oleh tindakan lain yang dilakukan. Dari segi moral memang tidak menjadi sesuai hal yang naïf melantik seseorang yang terkena kasus pidana, padahal masih banyak calon pemimpin yang tidak terkena kasus tindak pidana korupsi.

Apabila pemerintah melantik Hambit lalu tidak lama kemudian memberhentikannya, justru akan memunculkan kesan main-main dan tidak efisien. Langkah tersebut tentu tidak mendidik secara konstitusi. Jimly Asidiqie menyatakan bahwa, jangan hanya melihat konstitusi formal tetapi bagaimana dampak kemudharatannya, dampak negatif bagi pendidikan politik rakyat, " ujarnya. Jimly berpendapat, akan menjadi preseden yang buruk jika seorang tersangka masih dilantik sebagai pejabat publik. Apalagi Hambit Bintih saat ini tengah mendekam di dalam tahanan. ${ }^{5}$

4 K. Bertens, 2000, Pengantar Etika Bisnis, Kanisus, Yogyakarta, hal. 67.

5 Dedy Priatmojo, Syahrul Ansyari, Tersangka Korupsi Dilantik Jadi Bupati, Pemerintah Tak Mendidik, http://nasional.news.viva.co.id/news/read/469433tersangka-korupsi-dilantik-jadi-bupati--
Bangsa Indonesia dalam Pasal 1 ayat (3) UUD 45 telah dengan jelas memilih Negara hukum sebagai dasar negaranya. Oleh karena itu hanya teori Negara hukumlah yang dapat menjelaskan, mengapa Hambit Bintih yang menjadi tersangka tetap tidak dapat dilantik. Azas rechtmatigheid dan azas doelmatigheid, merupakan azas yang lahir dari suatu negara hukum. Kedua azas tersebut tentunya dapat digunakan guna menganalisis suatu perbuatan atau tindakan hukum pemerintah, yang tidak diatur dalam suatu peraturan perundangundangan.

Penetapan status tersangka bagi bupati terpilih saat ini ternyata menjadi faktor penghambat, disesabkan oleh pergeseran kepastian hukum Rechtmatig kearah Doelmatig atau kemanfaatan diluar faktor hukum yaitu karena tuntutan/ desakan masyarakat luas, etika politik dan efisiensi Pemerintahan. Berdasarkan hal tersebut maka, Bupati terpilih Hambit Bintih gagal dilantik.

Berdasarkan hal tersebut, maka penulis melihat ada tiga implikasi penetapan status tersangka bagi Bupati Terpilih dalam pemilihan umum kepala daerah dalam sistem ketatanegaraan Republik Indonesia yaitu etika dan sosial, politik, dan hukum. Ketiga implikasi tersebut dapat dijelaskan sebagai berikut:

a. Implikasi Etika dan Sosial yaitu penetapan status tersangka bagi Bupati Terpilih menimbulkan ketidak percayaan publik terhadap pemerintah.

b. Implikasi politik yaitu melahirkan kesempatan pihak lain untuk menjadi kepala daerah

pemerintah-tak-mendidik, diakses pada tanggal 18 Februari 2015. 
c. Implikasi hukum penetapan status tersangka bagi Bupati Terpilih yaitu tidak menghambat seseorang untuk melantik bupati terpilih menjadi bupati, karena dalam UU Pemerintahan Daerah hanya mengatur pemberhentian Bupati, bukan Bupati Terpilh.

\section{Penetapan Status Tersangka Bagi Bupati Terpilih dan Faktor Penghambat Seseorang Untuk Dilantik Sebagai Bupati}

Penetapan tersangka dalam konteks pelantikan bupati terpilih membawa dilematis tersendiri terhadap proses administrasi Negara. Pertama yaitu, seorang Bupati terpilih walaupun iaincumbent, namun pada dasarnya sebelum pelantikan, ia mengundurkan diri, sehingga dalam hal ini statusnya bukan sebagai bupati. Kedua kalaupun seorang bupati terpilih tersebut tidak dilantik atau diberhentikan, maka dalam status apa ia diberhentikan.

Pasal 108 b Undang-Undang 32 Tahun 2004 tentang Pemerintahan Daerah sebenarnya telah mengatur bahwa:

1) Dalam hal calon wakil kepala daerah terpilih berhalangan tetap, calon kepala daerah terpilih dilantik menjadi kepala daerah. Kepala daerah mengusulkan dua calon wakil kepala daerah kepada DPRD untuk dipilih.

2) Dalam hal calon kepala daerah terpilih berhalangan tetap, calon wakil kepala daerah terpilih dilantik menjadi kepala daerah.

3) Kepala daerah sebagaimana dimaksud pada ayat (1) mengusulkan dua calon wakil kepala daerah kepada DPRD untuk dipilih.
4) Dalam hal pasangan calon terpilih berhalangan tetap, partai politik atau gabungan partai politik yang pasangan calonnya meraih suara terbanyak pertama dan kedua mengusulkan pasangan calon kepada DPRD untuk dipilih menjadi kepala daerah dan wakil kepala daerah selambat-lambatnya dalam waktu 60 (enam puluh) hari.Untuk memilih wakil kepala daerah, pemilihannya dilakukan selambat-lambatnya dalam waktu 60 (enam puluh) hari.

Kondisi berhalangan tetap, membuat seorang kepala daerah tidak dapat dilantik. Penjelasan Pasal 29 Ayat (2) Huruf b UU No 32 tahun 2004 menyatakan bahwa, yang dimaksud dengan tidak dapat melaksanakan tugas secara berkelanjutan atau berhalangan tetap adalah menderita sakit yang mengakibatkan baik fisik maupun mental tidak berfungsi secara normal yang dibuktikan dengan surat keterangan dokter yang berwenang dan/atau tidak diketahui keberadaannya. Hal ini juga diatur sama dalam Pasal 139 Ayat(2) Huruf b UU No 23 tahun 2014 mengenai berhalangan tetap dan tidak dapat dilantik.

Penjelasan pasal tersebut menyatakan bahwa, yang dimaksud dengan "tidak dapat melaksanakan tugas secara berkelanjutan atau berhalangan tetap" adalah menderita sakit yang mengakibatkan baik fisik maupun mental tidak berfungsi secara normal yang dibuktikan dengan surat keterangan dokter yang berwenang, tidak diketahui keberadaannya, dan/atau tidak hadir dalam rapat tanpa keterangan apapun selama 3 (tiga) bulan berturut-turut. Sebagai Peraturan pelaksana Pasal 122 Ayat (2) b Peraturan Pemerintah Republik Indonesia 
Nomor 78 Tahun 2012 Tentang Perubahan Keempat Atas Peraturan Pemerintah Nomor 6 Tahun 2005 Tentang Pemilihan, Pengesahan Pengangkatan, Dan Pemberhentian Kepala Daerah Dan Wakil Kepala Daerah menyatakan bahwa, yang dimaksud dengan tidak dapat melaksanakan tugas secara berkelanjutan atau berhalangan tetap adalah menderita sakit yang mengakibatkan baik fisik maupun mental tidak berfungsi secara normal yang dibuktikan dengan surat keterangan dokter yang berwenang dan atau tidak diketahui keberadaannya.

Berdasarkan Pasal tersebut maka jelas bahwa faktor hambatan seseorang tidak dapat dilantik menjadi kepala daerah adalah halangan tetap. Konteks halangan tetap dalam UU No 23 tahun 2014 tentang Pemerintahan Daerah maupun Peraturan Pemerintah Republik Indonesia Nomor 78 Tahun 2012 Tentang Perubahan Keempat Atas Peraturan Pemerintah Nomor 6 Tahun 2005 Tentang Pemilihan, Pengesahan Pengangkatan, Dan Pemberhentian Kepala Daerah Dan Wakil Kepala Daerah adalah sama yaitu menderita sakit yang mengakibatkan baik fisik maupun mental tidak berfungsi secara normal dan atau tidak diketahui keberadaannya.

Pertanyaannya adalah, bagaimana dengan status tersangka, apakah juga dapat dikategorikan sebagai berhalangan tetap ?. Tersangka menurut Pasal 1 ayat (14) Kitab Undang Undang Hukum Acara Pidana (KUHAP) adalah seorang yang karena perbuatannya atau keadaannya, berdasarkan bukti permulaan yang cukup diduga sebagai pelaku tindak pidana. Artinya ia hanya disangka, berdasarkan bukti permulaan yang cukup, selain itu konsep tersangka masih memiliki perlindungan hukum, sesuai dengan azas praduga tidak bersalah.

Berdasarkan Pasal 83 UU. No. 23 tahun 2014 sebagai Undang-Undang maka jelas bahwa, dalam konteks hukum administrasi Negara atau hukum kenegaraan tetap menjunjung tinggi azas praduga tidak bersalah. Pasal 81 menjelakan "memberikan fasilitas untuk memberhentikan Kepala Daerah melalui DPR dan Pemerintah Pusat kepala daerah dan/atau wakil kepala daerah yang: (a) melanggar sumpah/janji jabatan kepala daerah/wakil kepala daerah; (b) tidak melaksanakan kewajiban kepala daerah dan wakil kepala daerah sebagaimana dimaksud dalam Pasal 67 huruf b; (c) melanggar larangan sebagaimana di-maksud dalam Pasal 76 kecuali huruf $\mathrm{c}$, huruf $\mathrm{i}$, dan huruf $\mathrm{j}$; dan/atau (d) melakukan perbuatan tercela.

Untuk melaksanakan pemberhentian tersebut Pemerintah Pusat melakukan pemeriksaan terhadap kepala daerah dan/atau wakil kepala daerah untuk menemukan buktibukti terhadap pelanggaran yang dilakukan oleh kepala daerah dan/atau wakil kepala daerah. Pasal 81 apabila di terjemahkan adalah ranah etika politik atau etika pemerintahan. Melanggar sumpah/janji jabatan kepala daerah/wakil kepala daerah, yaitu :

"Demi Allah/Tuhan, saya bersumpah/berjanji akan memenuhi kewajiban saya sebagai kepala daerah dengan sebaikbaiknya dan seadil-adilnya, memegang teguh Undang-Undang Dasar Negara Republik Indonesia Tahun 1945, dan menjalankan segala undang-undang dan peraturannya dengan selurus-lurusnya serta berbakti kepada masyarakat, nusa, dan bangsa".

Selain itu dalam Pasal 76 UU. No. 23 tahun 2014 yang menyatakan bahwa, Kepala 
daerah dan wakil kepala daerah dilarang:

a. membuat keputusan yang secara khusus memberikan keuntungan pribadi, keluarga, kroni, golongan tertentu, atau kelompok politiknya yang bertentangan dengan ketentuan peraturan perundang-undangan;

b. membuat kebijakan yang merugikan kepentingan umum dan meresahkan sekelompok masyarakat atau mendiskriminasikan warga negara dan/atau golongan masyarakat lain yang bertentangan dengan ketentuan peraturan perundang-undangan;

c. menjadi pengurus suatu perusahaan, baik milik swasta maupun milik nega$\mathrm{ra} /$ daerah atau pengurus yayasan bidang apa pun;

d. menyalahgunakan wewenang yang menguntungkan diri sendiri dan/atau merugikan Daerah yang dipimpin;

e. melakukan korupsi, kolusi, dan nepotisme serta menerima uang, barang, dan/atau jasa dari pihak lain yang mempengaruhi keputusan atau tindakan yang akan dilakukan;

f. menjadi advokat atau kuasa hukum dalam suatu perkara di pengadilan selain sebagaimana dimaksud dalam Pasal 65 ayat (1) huruf e;

g. menyalahgunakan wewenang dan melanggar sumpah/janji jabatannya;

h. merangkap jabatan sebagai pejabat negara lainnya sebagaimana ditetapkan dalam ketentuan peraturan perundang-undangan;

i. melakukan perjalanan ke luar negeri tanpa izin dari Menteri; dan j. meninggalkan tugas dan wilayah kerja lebih dari 7 (tujuh) Hari berturut-turut atau tidak berturut-turut dalam waktu 1 (satu) bulan tanpa izin Menteri untuk gubernur dan wakil gubernur serta tanpa izin gubernur untuk bupati dan wakil bupati atau wali kota dan wakil wali kota.

Larangan inipun dilimitasi oleh Pasal 81 huruf $c$ yaitu kecuali huruf $c$, huruf $i$, dan huruf $j$; dan/atau d. melakukan perbuatan tercela. Berdasarkan hal tersebut jelas, bahwa konteks Pasal 81 lebih mengarah ke prosesi persidangan etik, walaupun Pasal 76 huruf e juga mengatur perbuatan korupsi, kolusi, dan nepotisme serta menerima uang, barang, dan/atau jasa dari pihak lain yang mempengaruhi keputusan atau tindakan yang akan dilakukan, hal ini juga tetap harus melalui mekanisme pembuktian.

Pelantikan Bupati terpilih menjadi bupati tidak boleh menjadi penghalang proses hukum yang tengah dilakukan KPK. Sebab, jabatan bupati dan jabatan lainnya bukanlah penghalang bagi proses penegakan hukum (law enforcement). Hukum menganut azas persamaan di hadapan hukum (equality before the law) tanpa terkecuali, sebagai konsekuensi azas legalitas dalam Negara hukum. Berlakunya Persamaan (Similia Similius atau Equality before the Law) dalam Negara Hukum, Pemerintah tidak boleh mengistimewakan orang atau kelompok orang tertentu, atau memdiskriminasikan orang atau kelompok orang tertentu. Di dalam prinsip ini, terkandung (a) adanya jaminan persamaan bagi semua orang di hadapan hukum dan pemerintahan, dan (b) tersedianya mekanisme untuk menuntut perlakuan yang 
sama bagi semua warga Negara.

Adanya ketentuan yang mengharuskan pemeriksaan terhadap kepala daerah mendapatkan persetujuan dari Presiden juga bukan penghalang berlanjutnya proses hukum. Ketentuan Pasal 36 Ayat (1) UU No 32 Tahun 2004 menyebutkan, tindakan penyelidikan dan penyidikan terhadap kepala daerah dan atau wakil kepala daerah dilaksanakan setelah ada persetujuan tertulis dari Presiden atas permintaan penyidik.

Berdasarkan seluruh uraian tersebut, maka dapat dikatakan bahwa, penetapan status tersangka bagi bupati terpilih bukanlah faktor penghambat seseorang untuk dilantik sebagai bupati. Terdapat dua faktor yang menghambat seseorang dilantik menjadi Kepala Daerah, yaitu menjadi terdakwa sesuai dengan Pasal 31 UU No 32 tahun 2004 tentang Pemerintahan Daerah dan Pasal 83 UU No 23 tahun 2014 tentang Pemerintahan Daerah. Selain itu faktor yang menghambat seseorang dilantik menjadi Kepala Daerah, yaitu berhalangan tetap, sesuai Pasal 29 Ayat (2) Huruf $b$ dan Pasal 139 Ayat(2) Huruf b UU No 23 tahun 2014 tentang Pemerintahan Daerah.

\section{PENUTUP}

\section{Simpulan}

Berdasarkan hasil peneltian dan pembahasan yang dilakukan oleh penulis, maka dapat diambil suatu simulan sebagai berikut:

a. Implikasi penetapan status tersangka bagi Bupati Terpilih dalam pemilihan umum kepala daerah dalam sistem ketatanegaraan Republik Indonesia terbagi menjadi tiga implikasi yaitu sebagai berikut:

1) Implikasi Etika dan Sosial yaitu penetapan status tersangka bagi $\mathrm{Bu}$ - pati Terpilih menimbulkan ketidak percayaan publik terhadap pemerintah.

2) Implikasi politik yaitu melahirkan kesempatan pihak lain untuk menjadi kepala daerah.

3) Implikasi hukum penetapan status tersangka bagi Bupati Terpilih yaitu tidak menghambat seseorang untuk melantik bupati terpilih menjadi bupati, karena dalam UU Pemerintahan Daerah hanya mengatur pemberhentian Bupati, bukan Bupati Terpilh.

b. Penetapan status tersangka bagi bupati terpilih bukanlah faktor penghambat seseorang untuk dilantik sebagai bupati. Terdapat dua faktor yang menghambat seseorang dilantik menjadi Kepala Daerah, yaitu menjadi terdakwa tindak pidana korupsi, tindak pidana terorisme, makar, dan/atau tindak pidana terhadap keamanan Negara atau terbukti melakukan makar dan/atau perbuatan lain yang dapat memecah belah Negara Kesatuan Republik Indonesia yang dinyatakan dengan putusan pengadilan yang telah memperoleh kekuatan hukum tetap. Selain itu faktor yang menghambat seseorang dilantik menjadi Kepala Daerah, yaitu berhalangan tetap, sesuai Pasal 29 Ayat (2) Huruf b dan Pasal 139 Ayat (2) Huruf b UU No 23 tahun 2014 tentang Pemerintahan Daerah mengenai tidak dapat melaksanakan tugas secara berkelanjutan atau berhalangan tetap secara berturut-turut selama 6 (enam).

\section{Saran}

Pertama, Sebaiknya proses pelantikan tetap berjalan, namun setelah menjadi 
terdakwa, barulah Bupati tersebut dibebas tugaskan/ non aktif.

Kedua, Sebaiknya dibentuk regulasi mengenai transisi pelantikan bupati terpilh, yaitu pelantikan sementara Wakil Bupati terpilih menjadi PIt Bupati, yang selanjutnya apabila Bupati terplih terbukti, maka wakil bupati dapat menjadi Bupati, namun apabila tidak terbukti maka harkat dan martabat Bupat terpilh yang ditetapkan sebagai tersangka harus direhabilitasi dan dilantik secara ulang.

\section{DAFTAR PUSTAKA}

Bertens, K. 2000. Pengantar Etika Bisnis. Kanisus. Yogyakarta.

Rahardjo, Satjipto. 2006. IImu Hukum. Citra Aditya Bakti. Bandung.

Soekanto, Soerjono. 1984. Beberapa Permasalahan Hukum Dalam Kerangka Pembangunan di Indonesia. Penerbit Universitas Indonesia. Yogyakarta.

Priatmojo, Dedy. Syahrul Ansyari. Tersangka Korupsi Dilantik Jadi Bupati. Pemerintah Tak Mendidik. http://nasional.news. viva.co.id/news/read/469433-tersangkakorupsi-dilantik-jadi-bupati--pemerintahtak-mendidik. diakses pada tanggal 18 Februari 2015.

Setiawan, Aries dan Mohammad Adam. Anis: Kritik KPK Bukan Berarti Pro Koruptor "Kalau sekarang kan orang takut mengkritik KPK. karena takut dituduh pro koruptor."http://nasional.news.viva.co.id/ news/read/253267-kritik-kpk-bukanberarti-pro-koruptor. diakses pada tanggal 18 Februari 2015. 